\section{Kutsyk P., Ostapyuk $\mathbf{N}$.}

\title{
ORGANIZATION OF OPERATIONAL AND STRATEGIC CONTROLLING IN INTEGRATED ACCOUNTING SYSTEM
}

Надано визначення оперативного та стратегічного контролінгу, проаналізовано існуючи підходи до виділення об'єктів контролінгу, на основні чого ідентифіковано об'єкти оперативного та стратегічного контролінгу. Досліджено особливості функціонування систем стратегічного та оперативного контролінгу в сучасних умовах господарювання. Представлено уточнену систему аналітичних інструментів контролінгу з врахуванням особливостей їх застосування в контексті субсфер.

Ключові слова: об’єкти контролінгу, інструменти контролінгу, стратегічний контролінг, оперативний контролінг.

\section{Introduction}

At the present stage of the development of the accounting system, the issue of organization of the enterprise management process for the prevention and neutralization of threats and risks, as well as actualization of the potential opportunities and advantages of the enterprise to ensure economic security for increasing its efficiency is extremely topical. To do this, it is necessary to form a risk prevention system at the enterprise in order to effectively manage the enterprise. In such situation it is crucial to prevent risks, not eliminate them. Preventive policy is much more cost-effective and also allows to adhere to a management strategy at no additional cost, while respecting strategic goals. The efficiency of the functioning and the existence of enterprises directly depend on the degree of protection of their economic interests, which largely determines the economic security of the state as a whole. Thus, management of activities must organize a management system that would respond to existing risks and create a cover for preventive measures.

Controlling is one of the most effective tools of the enterprise management system in the context of neutralizing hazards, threats, risks and ensuring the economic security of the enterprise. It is thanks to the effectively built system of strategic and operational controlling that the enterprise will be able to raise the level of economic security, provide prompt warning of a possible crisis situation at the enterprise, adequately assess the enterprise's progress with regard to the chosen strategy, coordinate the work of all elements of the management system and the like.

\section{The object of research and its technological audit}

The object of research is the controlling system and its types through the prism of ensuring the economic security of the enterprise. The experience of enterprises in Western Europe, especially Germany, indicates the effectiveness and effectiveness of the introduction of controlling, which provides, and in some cases, stimulates the work of the entire management mechanism. At the same time, the use of controlling in domestic enterprises requires an understanding of its nature and the definition of a correlation with existing subsystems of accounting, audit, analysis and the possibility of implementation.

\section{The aim and objectives of research}

The aim of research is determination of the place, role and importance of controlling (in particular, strategic and operational) in the enterprise management system, including through the prism of research into the use of controlling tools in the context of its sub-spheres.

To achieve the aim of research, the following tasks are defined:

1. To investigate the differences between strategic and operational controlling.

2. To identify controlling objects, including in the context of strategic and operational controlling.

3. To provide suggestions on the instrumentation of controlling and its connection with the objects of controlling.

4. To focus on the features of building a system of strategic and operational controlling.

\section{Research of existing solutions of the problem}

A significant contribution to the development of theory and practice in the overall system of enterprise management and controlling has been made by such foreign scientists as: [1-5] who laid the theoretical foundations of the controlling concept, and also [6-8], who also focused on clarifying and developing controlling, as a sphere of science and a kind of practical activity.

Development of elements of the control system (objects, subjects, elements, spheres, etc.), as well as clarification of the category-conceptual apparatus, are devoted to the work of such domestic scientists as: [9-11] and others. However, a number of problematic issues remain in view of the interpretation of the role of controlling in the management system of the economic security of 
an enterprise, the identification of controlling objects and its instruments, the boundaries and peculiarities of using strategic and operational controlling in order to increase the efficiency of the enterprise.

\section{Methods of research}

In the process of research, general scientific methods and specific methods of economic analysis are used, including analysis and synthesis, method of logical generalization, analogies, comparative comparisons, monographic and graphoanalytical methods.

\section{Research results}

The speed of business processes in the era of informatization determines the need for a management system that has been proactively responding to possible threats. At the same time, the effectiveness of such management system is aimed at preventing the consequences of possible risks, however, acting within a certain development strategy of the enterprise.

Considering the problem of ensuring economic security through the use of the controlling system, in the special literature it is noted that certain departments of economic security should be engaged in a particular division. This is true. However, the activities of these units should have a single common goal and a clear communication: for the purpose of a balanced functioning of the enterprise. So, again we return to the need to determine the objectives of the enterprise and to agree among themselves all the directions of management activity. In this case, there is a problem of reconciling strategic and tactical goals. And the main purpose of the controlling system in corporate structures is subordination of current actions to strategic goals. Depending on this, strategic and operational controlling is distinguished.

Based on the results of the analysis of the definition of operational and strategic controlling, strategic controlling should be defined as a system of tools and methods that allow timely identification of the reasons for the deviation in achieving the strategic objectives of the enterprise, ensuring the long-term operation of the enterprise, in order to generate information for external and internal users. Unlike strategic controlling, operational controlling regulates and maintains the level of efficiency of the current enterprise management system in order to generate information for internal users. At the same time, it is necessary to emphasize the fact that operational and strategic controlling function in an inseparable connection: operational controlling as an instrument for regulating managerial processes is completely subordinated to the development objectives envisaged in the enterprise strategy. Simultaneously, the results of operational controlling affect the overall strategy, as current processes can show problems and inconsistencies for certain purposes. The basis of such effective interaction is in correctly defined objects of influence - objects of controlling.

The object of the controlling system is the factors of production, the processes of indicators of the effectiveness of their use and organization, the potential of the enterprise (number, fixed assets, capacity, volume of production and sales, etc.), as well as financial indicators compared with the forecasted ones [11]. Otherwise, the main objects of controlling are the costs of the enterprise and the responsibility centers in which the accumulation of costs and the formation of income take place [12].

After analyzing the literature, the views of the researchers are systematized relative to the object of controlling (Table 1).

The generalization of these thoughts gives grounds to draw a conclusion about the identification of objects of accounting, control, analysis, in particular, controlling. However, the validity of such thoughts is controversial. Controlling influences the course of economic processes, the effectiveness of the use of economic means and the introduction and maintenance of certain areas of activity (research and development, technological preparation of production). However, it should be recognized that managerial processes are the object of controlling. At least in corporate structures.

At present, as the research conducted by the author has shown, the issues of instrumentation of controlling and its connection with objects of controlling are not properly solved. In many publications, marginal analysis (analysis of coverage amounts) and analysis of deviations of actual values of indicators from their planned (normative) values are considered as the most used ones. In the best case, an attempt is made to differentiate the controlling instruments from the point of view of the operational or strategic levels of their functioning, without taking into account the fact that within the framework of these components, quite diverse tasks can be solved. According to the research results, it is established that controlling procedures conducted to support enterprise management must be carried out using a system of analytical tools, and a clear relationship between the tasks (sub-spheres) of controlling and the tools that provide their solutions should be established.

Table 2 presents the developed system of analytical tools, from which one can see that, on the one hand, certain spheres of controlling (tasks) use several instruments (primarily cost controlling), and on the other hand, some analytical tools allow solving quite diverse tasks.

The proposed system includes about 20 analytical tools, many of which are used in management accounting, management and marketing. At the same time, the tools are of a preventive nature. The introduced tools are a modification of existing tools for specific sub-spheres of controlling. This is primarily a segmental analysis, a system of control questions, an analysis of the «cost of replacing the supplier», an analysis of the feasibility of the system «just in time», an analysis of the distribution of overhead costs, an analysis of the image rationality of this service.

The most universal controlling tool is the functionalvalue analysis, suitable for effective application within at least half of the allocated sub-spheres of controlling. As a conclusion, the broad possibilities of functional-value analysis is the basis of its theoretical provisions, according to which any rationalized object is considered as a complex of functions for the corresponding valuable (costly) evaluation of their implementation.

Thus, controlling uses the available tools of accounting and analytical management. The task of controllers is the combination of successful tools to ensure the effective management of activities. The basis is information support of accounting. 
Table 1

Controlling objects

\begin{tabular}{|c|c|c|c|c|c|c|c|c|c|c|c|c|c|c|}
\hline $\begin{array}{l}\text { Controlling } \\
\text { objects }\end{array}$ & $\begin{array}{c}\text { M. Push- } \\
\text { kar } \\
{[11]}\end{array}$ & $\begin{array}{c}\text { Yu. Ja- } \\
\text { kovlev } \\
{[13]}\end{array}$ & $\begin{array}{c}\text { L. Su- } \\
\text { chareva } \\
\text { [12] }\end{array}$ & $\begin{array}{l}\text { G. She- } \\
\text { pitko } \\
{[14]}\end{array}$ & $\begin{array}{c}\text { P. Ore- } \\
\text { chovskiy. } \\
\text { [15] }\end{array}$ & $\begin{array}{c}\text { E. Anan- } \\
\text { kina } \\
{[16]}\end{array}$ & $\begin{array}{c}\text { A. Каг- } \\
\text { minskiy } \\
\text { [17] }\end{array}$ & $\begin{array}{c}\text { 5. Falco } \\
{[18]}\end{array}$ & $\begin{array}{l}\text { L. Po- } \\
\text { pova } \\
{[19]}\end{array}$ & $\begin{array}{l}\text { 0. Port- } \\
\text { nа } \\
\text { [20] }\end{array}$ & $\begin{array}{l}\text { Kh. Fol- } \\
\text { mut } \\
\text { [21] }\end{array}$ & $\begin{array}{l}\text { Deyh- } \\
\text { le A. } \\
\text { [6] }\end{array}$ & $\begin{array}{c}\text { P. Khor- } \\
\text { vat } \\
\text { [22] }\end{array}$ & $\begin{array}{c}\text { M. Slut- } \\
\text { skin } \\
\text { [23] }\end{array}$ \\
\hline $\begin{array}{l}\text { 1. Material and } \\
\text { technical support }\end{array}$ & - & - & - & - & - & - & - & - & - & - & - & - & - & - \\
\hline $\begin{array}{l}\text { 1.1. Cash, } \\
\text { non-current and } \\
\text { intangible assets }\end{array}$ & + & - & - & - & - & - & - & - & - & - & - & - & - & - \\
\hline $\begin{array}{l}\text { 1.2. Staff and } \\
\text { wages }\end{array}$ & + & - & - & - & - & - & - & - & - & - & + & - & - & - \\
\hline 1.3. Holdings & + & - & - & - & - & - & + & - & - & - & - & - & - & + \\
\hline $\begin{array}{l}\text { 1.4. Labor, ma- } \\
\text { terial and finan- } \\
\text { cial resources }\end{array}$ & - & - & - & - & + & - & - & - & - & - & - & - & - & - \\
\hline $\begin{array}{l}\text { 1.5. Supply } \\
\text { of material } \\
\text { and technical } \\
\text { resources }\end{array}$ & - & - & - & - & + & - & - & - & - & - & - & - & - & + \\
\hline $\begin{array}{l}\text { 1.6. Policy of } \\
\text { relations with } \\
\text { suppliers }\end{array}$ & - & - & - & - & + & - & - & - & - & - & - & - & - & + \\
\hline $\begin{array}{l}\text { 2. Business } \\
\text { processes }\end{array}$ & - & - & - & - & - & - & - & - & - & - & - & - & - & - \\
\hline $\begin{array}{l}\text { 2.1. Supply } \\
\text { (logistics) }\end{array}$ & + & - & - & - & - & - & + & + & - & - & + & - & - & - \\
\hline 2.2. Production & + & - & - & - & - & - & - & - & - & - & - & + & - & + \\
\hline 2.3. Marketing & + & - & - & - & - & - & - & + & - & - & - & + & - & - \\
\hline 2.4. Investing & + & + & - & + & - & - & + & + & - & - & + & + & + & - \\
\hline $\begin{array}{l}\text { 3. Functional } \\
\text { areas of activity }\end{array}$ & - & - & - & - & - & - & - & - & - & - & - & - & - & - \\
\hline $\begin{array}{l}\text { 3.1. Innovation } \\
\text { activity }\end{array}$ & + & - & - & - & - & - & + & + & + & - & - & - & - & - \\
\hline $\begin{array}{l}\text { 3.2. Marketing, } \\
\text { management }\end{array}$ & + & - & - & - & - & - & - & - & - & - & - & - & - & + \\
\hline $\begin{array}{l}\text { 3.3. financial } \\
\text { activities }\end{array}$ & + & + & - & - & - & - & + & + & + & + & + & + & + & - \\
\hline $\begin{array}{l}\text { 3.4. Investment } \\
\text { activities }\end{array}$ & + & + & - & - & - & - & + & + & - & + & - & - & - & - \\
\hline $\begin{array}{l}\text { 4. Expenses } \\
\text { (expenses) }\end{array}$ & - & + & + & + & - & + & - & - & + & + & + & + & + & - \\
\hline $\begin{array}{l}\text { 5. Research and } \\
\text { development } \\
\text { work, technologi- } \\
\text { cal preparation } \\
\text { of production }\end{array}$ & - & - & - & - & - & - & - & - & - & - & - & - & - & - \\
\hline $\begin{array}{l}\text { 5.1. Research } \\
\text { work }\end{array}$ & - & - & - & - & - & - & - & - & - & - & - & - & - & + \\
\hline $\begin{array}{l}\text { 5.2. Engineering } \\
\text { design }\end{array}$ & - & - & - & - & - & - & - & - & - & - & - & - & - & + \\
\hline $\begin{array}{l}\text { 5.3. Technologi- } \\
\text { cal preparation } \\
\text { of production }\end{array}$ & - & - & - & - & - & - & - & - & - & - & - & - & - & + \\
\hline
\end{tabular}

Note: Italicized objects are the objects of strategic controlling. 
Controlling tools and peculiarities of their application in the context of controlling sub-spheres

\begin{tabular}{|c|c|}
\hline Sub-spheres (tasks) of controlling & Controlling tools \\
\hline Technical design controlling & Functional cost analysis \\
\hline $\begin{array}{l}\text { Controlling of the technological preparation } \\
\text { of production }\end{array}$ & Functional cost analysis \\
\hline $\begin{array}{l}\text { Controlling of the requirements for material } \\
\text { and technical resources }\end{array}$ & Marginal analysis, Factor analysis of deviations \\
\hline $\begin{array}{l}\text { Controlling of the costs of inventory of material } \\
\text { and technical resources }\end{array}$ & Analysis of the experience curve, Analysis of the effect of scales \\
\hline $\begin{array}{l}\text { Controlling of the supply of material and techni- } \\
\text { cal resources and supplier relations policies }\end{array}$ & $\begin{array}{l}\text { Analysis of inventory costs, ABC analysis, XYZ analysis; Cost analysis for "replacement of the supplier», } \\
\text { Feasibility analysis of the system "Dn time» }\end{array}$ \\
\hline Production cost controlling & $\begin{array}{l}\text { Functional cost analysis, System of control questions, Factor analysis of deviations, ABC analysis, XYZ analysis, } \\
\text { Feasibility analysis of the system "on time», Analysis of the distribution of overhead costs, Analysis of the } \\
\text { experience curve, Analysis of the effect of scales, Analysis of the cost of quality, Life cycle analysis, Financial } \\
\text { analysis (retrospective, current) Financial analysis (prospective), Econometric methods, Budget planning, Linear } \\
\text { programming, Network planning, "Kaizen-costing", CVP-analysis, EOQ-model, Bottleneck analysis, JIT }\end{array}$ \\
\hline Production capabilities (capacities) controlling & Marginal analysis \\
\hline Quality cost controlling & $\begin{array}{l}\text { Functional cost analysis, Factor analysis of deviations, Analysis of the experience curve, Analysis of the } \\
\text { cost of quality, Financial analysis (retrospective, current), Potential analysis, Competition analysis, Financial } \\
\text { analysis (prospective) }\end{array}$ \\
\hline Product policy Controlling & Segment analysis, Life cycle analysis, Analysis of strategic gaps, Portfolio analysis \\
\hline Price controlling & Functional cost analysis, Marginal analysis, Segment analysis \\
\hline Customers controlling & ABC analysis \\
\hline Communication policy controlling & Functional cost analysis, Segment analysis, Analysis of discounts to sales prices \\
\hline Competitars contralling & Benchmarking, SWOT analysis \\
\hline After-sales service controlling & Functional cost analysis, Analysis of the rationality of after-sales service and its outsourcing \\
\hline Innovation and research controlling & $\begin{array}{l}\text { Analysis of costs for quality, Life cycle analysis, Portfolio analysis, SWOT analysis, Investment analysis (static } \\
\text { methods) Financial analysis (retrospective, current), Target-costing, Capacity analysis, Competition analysis, } \\
\text { Risk analysis, Investment analysis (dynamic, modeling, scenario development), Financial analysis (prospective), } \\
\text { GAP analysis, PEST analysis, EVA, Econometric methods, Scenario development }\end{array}$ \\
\hline Investment controlling & $\begin{array}{l}\text { Functional cost analysis, Analysis of costs for quality, Portfolio analysis, SWOT analysis, Investment analysis } \\
\text { (static methods), Financial analysis (retrospective, current), Potential analysis, Competition analysis, Risk } \\
\text { analysis, Investment analysis (dynamic, modeling, scenario development), Financial analysis (prospective), } \\
\text { GAP analysis, Econometric methods, Scenario development, Budget planning, Linear programming, Network } \\
\text { planning, CF analysis }\end{array}$ \\
\hline Business process controlling & $\begin{array}{l}\text { Functional cost analysis, Factor analysis of deviations, ABC analysis, XYZ analysis, Cost analysis, Life cycle } \\
\text { analysis, Financial analysis (retrospective, current), Financial analysis (prospective), EVA, Econometric methads, } \\
\text { Budget planning, Linear programming, Network planning, CVP analysis, EOQ model, Bottleneck analysis, JIT, } \\
\text { ABC method (process), Reengineering, Modeling }\end{array}$ \\
\hline Risk controlling & $\begin{array}{l}\text { Analysis of costs for quality, Life cycle analysis, Portfolio analysis, SWOT analysis, Investment analysis (static } \\
\text { methods), Financial analysis (retrospective, current), Target-costing, Capacity analysis, Competition analysis, } \\
\text { Risk analysis, Investment analysis (dynamic, modeling, scenario development), GAP analysis, PEST analysis, } \\
\text { Econometric methods, Scenario development, Linear programming, BSC, Graph theory }\end{array}$ \\
\hline
\end{tabular}

Note: Italicized objects are the objects of strategic controlling.

An important and necessary element is the fixing of certain controlling procedures in the internal administrative document. It is expedient and obligatory to combine the provisions of such administrative document with the Regulations on Accounting Policies and Management Accounting Standards. The latter is the basis for the implementation of operational controlling.

In the economic literature, much attention is paid to the issues of the direction of the action of strategic controlling. The establishment of strategic goals begins with an analysis of the factors of the external and internal environment. The choice of specific factors is an individual matter for each particular enterprise. The process of choice depends on the objectives, the specific situation, the capabilities of the accounting system and analysis. At the same time, the analysis of internal and external factors can be carried out by a number of instruments determined by the theory and practice of economic analysis.

Strategic controlling coordinates the functions of strategic planning, control and strategic information management system. The strategic planning objective is ensuring the long-term successful operation of the enterprise. To do this, it is necessary to formulate and implement strategies for finding, construction and maintaining the potential for success (profitability). If an enterprise can provide a solution to existing, variable or new customer problems that is more effective than its competitors, it means its ability to generate new potentials for success. The potential for success can also be divided into external and internal. External potentials depend on a successful 
combination of «product/market», internal potentials are information, structural, technical, financial, personnel and other potentials.

When developing the strategy, it is necessary to seek and specify the possible alternative solutions that allow achieving the set goals and eliminating the available «hatches». It is necessary to develop as many alternative strategies as possible on the basis of proposals, expectations and forecasts using appropriate tools.

Due to incomplete quantitative and qualitative information, and also due to the open (uncertain) planning horizon, the evaluation of alternatives generated in the framework of strategic planning is significantly hampered.

Operational controlling involves creating and maintaining the level of efficiency of the system achieving the current local objectives of the firm, management of the efficiency of the enterprise. This kind of controlling has its own peculiarities in the controlling system. First, it is focused on operational (current) planning. Secondly, operational controlling is the basis for the success of strategic controlling and strategic planning. In the framework of the tasks of this type of controlling, more local problems are solved, therefore, they are quite broad here than in strategic controlling. In controlling, it is strategically important to assess the effectiveness of the management of the enterprise. Usually the methods of comparative analysis, deviations, index analysis, additive models are used. However, the important task of organizing the operational control system is to synchronize with the selection of tools and the direction of their actions within certain strategic actions.

Accordingly, a feature of operational controlling is necessary - a principled approach to the decomposition of individual indicators into components to subordinate to the achievement of strategic goals.

The most significant instrumental support for operational controlling is the budgeting system, which allows management to outline the way the enterprise develops, provide crisis situations and avoid them, and optimally allocate resources among the units of the organization. The issues of budgeting as a tool for controlling are most fully covered in the domestic economic literature by two authors' groups [16] and [17].

As an instrumental aspect of operational controlling of budgeting is aimed at solving tasks such as implementation of current (short-term) planning, it allows the most optimal allocation of available resources in the organization; evaluation of the organization. Thus, the budget is created on the basis of joint efforts of the controlling specialist.

The system of operational controlling is necessary to maintain competitiveness, and forces the modern to improve its systems and management procedures.

Compilation of information and transfer in an acceptable form is the main task of the reporting system. From the reports it should be clear to what extent in the relevant functional areas of the enterprise the intended goals are realized and where additional measures should be implemented.

\section{SWOT analysis of research results}

Strengths. The strength of research is a detailed analysis of the essence of controlling, its directions within its distinguished species.
Weaknesses. The weak side is that in the Ukrainian enterprises a clear delimitation of controlling boundaries leads to the complexity of developing a mechanism for its use. In particular, it is additionally necessary to develop technological maps of functions, tools, and the order of interaction with other control subsystems.

Opportunities. Opportunities for further research are adaptation of the experience of foreign countries in building a controlling system at Ukrainian enterprises.

Threats. Threats to the results are that a number of subjective factors affect the possibility of building a controlling system at an enterprise, including understanding and professional skills of managers.

\section{Conclusions}

As a result of the conducted research it is established:

1. Controlling is an effective management tool that is designed to create information and technological support for the effective operation of the enterprise, including to raise the level of economic security, to provide prompt warning of a possible crisis situation in the enterprise, to adequately assess the enterprise's progress in relation to the chosen strategy, to coordinate the work of all elements of the management system, etc.

Research allows to identify operational and strategic controlling, the latter of which is a system of tools and methods that allow timely identification of the reasons for deviation in achieving the strategic objectives of the enterprise, ensuring the long-term operation of the enterprise, with the purpose of generating information for external and internal users. At the same time, operational controlling controls and maintains the level of efficiency of the current enterprise management system in order to generate information for internal users.

2. Controlling objects are the processes of management subsystems aimed at achieving the set strategies of the enterprise. In terms of operational controlling, we should talk about the direction of the state and changes of individual objects of the enterprise's property and business processes.

3. Controlling procedures that are carried out to support the management of an enterprise must be carried out using a system of analytical tools, and a clear relationship between the tasks (sub-spheres) of controlling and the tools that provide their solutions should be established. As a result of the research, the system of 20 analytical controlling tools is presented, many of which are used in management accounting, management and marketing. Along with this, tools developed by the author themselves or those that are a modification of existing tools for specific sub-controlling are introduced in the system.

4. Strategic controlling coordinates the functions of strategic planning, control and strategic information management system. Operational controlling involves creating and maintaining the level of efficiency of the system achieving the current local objectives of the company, management of the enterprise efficiency.

\section{References}

1. Mayer, E. Handbuch Controlling [Text] / E. Mayer, J. Weber. Stuttgart: Vahlen Verlag, 1990. - 423 p.

2. Weber, J. Einfuhrung in das Controlling [Text] / J. Weber. Stuttgart: Schaffer Poeschel, 1998. - 437 p. 
3. Hahn, D. Entwicklungstendenzen der strategischen Führung [Text] / D. Hahn // Technologie und Management. - 1992. Vol. 41, № 2. - P. 10-21.

4. Hahn, D. Planirovanie i kontrol': kontseptsiia kontrollinga [Text]: Translation from Germany / D. Hahn; ed. by A. A. Gurchak, L. G. Golovach, M. L. Lukashevich. - Moscow: Finance and statistics, 1997. - 800 p.

5. Horvath, P. Vahlens grosses Controllinglexikon [Text] / P. Horvath, T. Reichmann. - München: Beck, Vahlen, 1993. - 682 p.

6. Deyhle, A. Controller-Praxis. Führung durch Ziele, Planung und Controlling [Text] / A. Deyhle. - München: ControllerAkademie, Gauting, 2001. - 176 p.

7. Deyhle, A. Controller-Praxis [Text] / A. Deyhle, K. Eiselmayer, G. Kleinhietpass. - Freiburg: Verlag für ControllingWissen, 2016. - 350 p.

8. Reichmann, T. Controlling mit Kennzahlen [Text] / T. Reichmann. Muenchen: Vahlen, 2011. - 824 p. doi:10.15358/9783800643752

9. Brokhun, N. S. Bukhhalterskyi oblik yak instrument informatsiinoho zabezpechennia systemy kontrolinhu [Text]: PhD thesis: 08.00.09 / N. S. Brokhun. - Zhytomyr: Zhytomyr State Technological University, 2010. - $20 \mathrm{p}$.

10. Holov, S. F. Upravlinskyi oblik [Text]: Handbook / S. F. Holov. - Kyiv: Libra, 2003. - 704 p.

11. Pushkar, M. S. Kontrolinh - informatsiina pidsystema stratehichnoho menedzhmentu [Text]: Monograph / M. S. Pushkar, R. M. Pushkar. - Ternopil: Kart-blansh, 2004. - 370 p.

12. Suhareva, L. A. Kontroling - osnova upravleniia biznesom [Text] / L. A. Suhareva, S. N. Petrenko. - Kyiv: Elga, NikaTsentr, 2002. - 208 p.

13. Yakovliev, Yu. P. Kontrolinh na bazi informatsiinykh tekhnolohii [Text] / Yu. P. Yakovliev. - Kyiv: Tsentr navchalnoi literatury, 2006. - 318 p.

14. Shepitko, H. F. Kontrolinh [Text]: Handbook / H. F. Shepitko. Kyiv: European University, 2005. - 136 p.

15. Orehovskii, P. A. Kontrolling [Text]: Handbook / P. A. Orehovskii. - Obninsk: International Academy of Modern Knowledge, 2000. - 187 p.

16. Anankina, E. A. Kontrolling kak instrument upravleniia predpriiatiem [Text] / E. A. Anankina, S. V. Danilochkin, N. G. Danilochkina et al; ed. by N. G. Danilochkina. - Moscow: YuNITI, 2002. - 279 p.

17. Karminskii, A. M. Kontrolling v biznese. Metodologicheskie i prakticheskie osnovy postroeniia kontrollinga $\mathrm{v}$ organizatsiiah [Text] / A. M. Karminskii, N. I. Olenev, A. G. Primak, S. G. Falko.Ed. 2. - Moscow: Finance and statistics, 2002. - 256 p.
18. Karminskii, A. M. Kontrolling [Text]: Handbook / A. M. Karminskii, S. G. Falko, A. A. Zhevaga, N. Yu. Ivanova; ed. by A. M. Karminskii, S. G. Falko. - Moscow: Finance and statistics, 2006. - 336 p.

19. Popova, L. V. Kontroling [Text]: Handbook / L. V. Popova, R. E. Isakova, T. A. Golovina. - Moscow: Business and Service, 2003. - 192 p.

20. Portna, O. V. Kontrolinh [Text]: Handbook / O. V. Portna. Lviv: Mahnoliia 2006, 2008. - 240 p.

21. Folmut, H. I. Instrumenty kontrollinga ot A do Ya [Text]: Translation from Germany / H. I. Folmut; ed. by M. L. Lukashevich, E. N. Tihonenkova. - Moscow: Finance and statistics, 2003. - 288 p.

22. Horvat, P. Kontseptsiia kontrollinga: Upravlencheskii uchet Sistema otchetnosti. Biudzhetirovanie [Text] / P. Horvat et al. Moscow: Alpina Business Books, 2005. - 269 p.

23. Slutskin, M. L. Razrabotka sistemy kontrollinga na promyshlennom predpriiatii: teoreticheskie osnovy i metodologiia [Text] Dissertation Thesis of Doctor of Economic Sciences: 08.00.05 M. L. Slutskin. - Saint Petersburg, 2005. - 35 p.

\section{ОРГАНИЗАЦИЯ ОПЕРАТИВНОГО И СТРАТЕГИЧЕСКОГО} КОНТРОЛЛИНГА В УСЛОВИЯХ ИНТЕГРИРОВАННОЙ СИСТЕМЫ YЧETA

Даны определения оперативного и стратегического контроллинга, проанализированы существующие подходы к выделению объектов контроллинга, на основные чего идентифицированы объекты оперативного и стратегического контроллинга. Разработана система аналитических инструментов контроллинга с учетом особенностей их применения в контексте субсфер. Исследовано порядок функционирования систем стратегического и оперативного контроллинга в современных условиях хозяйствования.

Ключевые слова: объекты контроллинга, инструменты контроллинга, стратегический контроллинг, оперативный контроллинг.

Kutsyk Petro, PhD, Professor, Department of Accounting, Lviv University of Trade and Economics, Ukraine, e-mail: kucykpetro@mail.ru ORCID: http://orcid.org/0000-0001-8514-852X

Ostapyuk Natalia, Doctor of Economic Sciences, Professor, Department of Accounting and Taxation, Kyiv National Economics University named after Vadym Hetman, Ukraine, e-mail: ostapiuk@ukr.net, ORCID: http://orcid.org/0000-0003-2347-3815
Grinko A., Hrynko P.

\section{RESEARCHES OF MODERN DEVELOPMENT OF BUSINESS ENVIRONMENT IN UKRAINE}

Досліджено поняття «підприємнищьке середовище». Проаналізовано погляди вчених щодо його суті. Охарактеризовано зовнішні та внутрішні фактори, що впливають на ефективність розвитку підприємницького середовища та визначають його структуру. Проведено комплексну оцінку сучасного стану українського підприємницького середовища, яка дозволила визначити основні проблемні параметри та надати характеристику ділового та інвестиційного клімату в країні.

Ключові слова: підприємницьке середовище, управління бізнесом, інституційні механізми, прийняття рішень.

\section{Introduction}

The modern significance of the methodological substantiation of institutional mechanisms for ensuring the effectiveness of the development of the business environment is due to the growing role of entrepreneurship and the factors of activating its business activity in increasing the economic potential of the Ukrainian economy and in- 